\title{
KODEKS DOBROG ADMINISTRATIVNOG PONAŠANJA ZA SLUŽBENIKE EVROPSKE KOMISIJE U NJIHOVIM ODNOSIMA SA JAVNOŠĆU
}

\begin{abstract}
Manja ĐURIĆ DŽAKIĆ*
Apstrakt: Rad službenika u institucijama Evropske unije treba da bude u skladu sa njenim primarnim i sekundarnim zakonodavstvom. Međutim, zakonitost u radu je samo jedan aspekt ponašanja službenika. Ostali aspekti su ponašanje prema zaposlenima, strankama i medijima, odnosno javnosti. Da bi sve komponente ponašanja službenika bile obuhvaćene postoji mogućnost da se donese Kodeks ponašanja. Cilj ovog rada je upoznavanje sa Kodeksom ponašanja službenika Evropske komisije u njihovim odnosima sa javnošću (Kodeks). U radu se polazi od hipoteze da je Kodeks odlično sredstvo za konkretizaciju prava na dobru upravu i podizanje kvaliteta rada službenika Evropske komisije. Rezultati do kojih se došlo u ovom radu ukazuju da je Evropska komisija kroz Kodeks nastojala da utiče na ponašanje svojih službenika prema strankama i medijima, da obezbjedi zaštitu podataka i omogući korištenje žalbe u slučaju nepoštovanja odredbi Kodeksa.

Ključne riječi: kodeks ponašanja službenika EU, Evropska komisija, odnos prema javnosti, dobra uprava.
\end{abstract}

\section{1) UVOD}

Evropska komisija je nastala fuzijom izvršnih organa 1965. godine. To je učinjeno donošenjem Ugovora o osnivanju jedinstvenog Savjeta i jedinstvene Komisije Evropskih zajednica ${ }^{1}$ kojim je zamjenjena Visoka vlast Evropske zajednice za ugalj i čelik kao i Komisija Evropske ekonomske zajednice i Komisija Evropske zajednice

\footnotetext{
*Fakultet političkih nauka Univerziteta u Banjaluci, e-mail: manja.djuric@fpn.unibl.org

${ }^{1}$ Ugovor o osnivanju jedinstvenog Savjeta i jedinstvene Komisije Evropskih zajednica (Traité instituant un Conseil unique et une Commission unique des Communautés européennes) potpisan
} 
za atomsku energiju. ${ }^{2} \mathrm{Na}$ taj način je dobijen jedan izvršni organ za tri evropske zajednice. To je nadnacionalni organ koji se stara o opštem interesu zajednice.

Komisija predstavlja pokretački motor EU i u njoj radi veliki broj zaposlenih. ${ }^{3}$ Zaposleni nastoje da svoj posao obavljaju kvalitetno i u opštem interesu Zajednice. Da bi njihov rad i ponašanje bilo profesionalno, objektivno i kvalitetno bilo je potrebno da se donese Kodeks ${ }^{4}$ koji će zaposleni u Komisiji primjenjivati u svakodnevnom radu.

Kodeks vuče svoje korijene iz Kodeksa dobrog administrativnog ponašanja kojeg je predložio Roj Peri (Roy Perry), poslanik Evropskog parlamenta, čiji nacrt je uradio Jakob Sederman (Jacob Söderman), tadašnji Evropski ombudsman, a koji je 6. septembra 2001. godine Evropski parlament odobrio svojom rezolucijom. Kodeks dobrog administrativnog ponašanja imao je zadatak da konkretizuje pravo na dobru upravu koje je predviđeno Poveljom o osnovnim pravima Evropske unije usvojene 2000 . godine. ${ }^{5}$

Imajući u vidu značaj dobrog administrativnog ponašanja, Evropski ombudsman je pozvao sve institucije i organe Evropske unije da usvoje svoje kodekse dobrog administrativnog ponašanja. Evropska komisija se odazvala tom pozivu i usvojila je 2000. godine Kodeks o dobrom ponašanju za osoblje Evropske komisije u odnosima sa javnošću koji predstavlja sastavni dio Poslovnika Komisije. ${ }^{6}$

je 8.4.1965. godine u Briselu, a stupio je na snagu 1.7.1965. godine. Originalni tekst Ugovora je na francuskom jeziku. U literaturi na engleskom jeziku može se naći pod nazivom "The Mearger Treaty".

${ }^{2}$ Traité instituant un Conseil unique et une Commission unique des Communautés européennes, Article 9, Journal officiel des Communautés européennes, № 152/2, 13.7.67.

${ }^{3}$ Prema podacima o broju zaposlenih u Evropskoj komisije sa 1. januarom 2021. godine zaposleno je 32.281. Prema mjestu zaposlenja najveći broj radi u Briselu 21.481 (66,5\%), u Luksemburgu 3.718 (11,5\%), u ostalim dijelovima EU 3.447 (10,7\%), a van EU 3.635 (11,3\%). Prema državama članicama iz kojih dolaze zaposleni na prvom mjestu je Belgija sa 4.791 $(14,8)$, koju slijede Italija sa $4.141(12,8 \%)$, Francuska sa $3.246(10,1 \%)$, Španija sa 2.560 $(7,9 \%)$ i Njemačka sa 2.104 (6,5\%) zaposlenih. Ostatak broja zaposlenih dijele ostale države članice. Vidi HR Key Figures Staff Members, European Commission 2021, 4. May 2021, https://ec.europa.eu/info/sites/default/files/european-commission-hr_key_figures_ 2021_en.pdf, (18.5.2021).

${ }^{4}$ Kodeks o dobrom ponašanju za osoblje Evropske komisije u odnosima sa javnosti, Poslovnik Komisije, (SL L 308, 8.12.2000).

5 „Europski kodeks dobrog upravnog ponašanja europskog ombudsmana”, Hrvatska javna uprava, 2009, br. 4, str. 966-967; Ivan Koprić, Anamarija Musa, Goranka Lalić Novak, "Good Administration as a Ticket to the European Administrative Space", Zbornik Pravnog fakulteta Zagreb, 2011, broj 5, p. 1523-1524.

${ }^{6}$ Ivan Koprić, Anamarija Musa, Goranka Lalić Novak, "Good Administration as a Ticket to the European Administrative Space" op. cit., p. 1526. 
Kodeks u svom prvom dijelu ima tri odlomka: kvalitetna služba, svrha i oblast djelovanja. Drugi dio se dijeli na generalne principe, smjernice za dobro administrativno ponašanje, informacije o pravima zainteresovanih strana, postupanje po upitima, zaštita ličnih podataka i povjerljivih informacija i žalbe.

\section{2) KVALITETNA SLUŽBA, SVRHA KODEKSA I NJEGOVA PRIMJENA}

Kodeks dobrog administrativnog ponašanja za službenike Evropske komisije u njihovim odnosima sa javnošću (Kodeks) usvojen je u namjeri da se omogući Evropskoj komisiji da ispuni obaveze dobrog administrativnog ponašanja posebno u odnosima koje ima sa javnošću, poštujući standard dobrog administrativnog ponašanja koji je u skladu sa pravom na dobru upravu iz Povelje o osnovnim pravima Evropske unije prema kojem svaka osoba ima pravo da se prema njenim poslovima institucije, organi i agencije Unije odnose nepristrasno, pravično i u razumnom roku. Prema Povelji pravo na dobru upravu uključuje pravo svake osobe na saslušanje prije preduzimanja bilo kakve pojedinačne mjere koja bi na nju mogla nepovoljno uticati, pravo svake osobe na pristup svom spisu, uz poštovanje zakonitih interesa povjerljivosti te profesionalne i poslovne tajne i obavezu uprave da obrazloži svoje odluke. Pored navedenog, svaka osoba ima pravo da joj Unija nadoknadi svaku štetu koju njene institucije ili službenici prouzrokuju pri obavljanju svojih dužnosti, u skladu sa opštim načelima koja su zajednička pravima država članica. Ovome se dodaje i pravo svake osobe da se može pisanim putem obratiti institucijama Unije na jednom od jezika Ugovora i da mora dobiti odgovor na istom jeziku.?

Komisija i njeni službenici imaju dužnost da služe interesima Zajednice i u javnom interesu. Javnost legitimno očekuje kvalitetnu službu i administraciju koja je otvorena, dostupna i prikladno vođena. Kvalitetna služba zahtijeva od Komisije i njenih službenika da budu učtivi, objektivni i nepristrasni. ${ }^{8}$ Kao što vidimo postavljeni zahtjevi za službenike Evropske komisije su u skladu sa stavom koji se može naći u teoriji da „u odnosu na zadatke koje izvršava, upravni službenik je dužan da savesno, odgovorno i stručno obavlja poslove koji su mu povjereni" a, $\mathrm{s}$ druge strane, „u odnosu na ljude sa kojima radi, upravni službenik je dužan da se kolegijalno odnosi prema njima i da bude kooperativan kada sa njima sarađuje". 9

\footnotetext{
${ }^{7}$ Margrét Vala Kristjánsdóttir, “Good Administration as a Fundamental Right”, Icelandic Review of Politics and Administration, Vol. 9, Issue 1, 2013, p. 240; Vidi član 41, pravo na dobru upravu, Povelja Evropske unije o osnovnim pravima, SL C 202, 7.6.2016, str. 389-405.

${ }^{8}$ Vidi odlomak pod naslovom "Kvalitetna usluga" u Kodeksu o dobrom ponašanju za osoblje Evropske komisije u odnosima sa javnosti, Poslovnik Komisije, (SL L 308, 8.12.2000), str. 14.

${ }_{9}^{9}$ Stevan Lilić et al., Upravno pravo, Savremena administracija, Beograd, 1999. godina, str. 42.
} 
Kodeks je obavezujući za sve službenike na koje se odnose Kadrovska pravila ${ }^{10}$ za funkcionere i uslovi za zapošljavanje drugih službenika Evropskih zajednica (Kadrovska pravila) i druge odredbe o odnosima između Komisije i njenih službenika koje su primjenljive na funkcionere i druge službenike Evropskih zajednica. Pored njih, Kodeks je obavezujući i za lica koja su zaposlena u skladu sa ugovorima privatnog prava, eksperti raspoređeni iz nacionalnih civilnih službi i pripravnici itd. koji rade za Evropsku komisiju. ${ }^{11}$

\section{3) GENERALNI PRINCIPI}

U odnosima sa javnošću Komisija poštuje sljedeće generalne principe: zakonitost, nediskriminaciju i jednak tretman, proporcionalnost i konzistentnost.

U skladu sa principom zakonitosti Evropska komisija postupa u skladu sa pravom i primjenjuje pravila i procedure predviđene u komunitarnom zakonodavstvu, tako da nijedan postupak Evropske komisije ne smije biti protivan važećim pravilima. ${ }^{12}$ Princip nediskriminacije i jednakog tretmana Evropska komisija poštuje prema svima bez obzira na nacionalnost, pol, rasno ili etničko porijeklo, religiju ili uvjerenje, invalidnost, dob ili seksualnu orijentaciju. Ovo je u skladu sa članom 21 Povelje o osnovnim pravima Evropske unije kojim se zabranjuje diskriminacija. Ako je prekršen princip nediskriminacije i jednakog tretmana pojedinci mogu podnijeti žalbu na zakonodavstvo Evropske unije ili nacionalno zakonodavstvo kojim se provodi pravo Evropske unije. ${ }^{13}$ Poštovanje principa proporcionalnosti se ogleda u obavezi Evropske komisije da osigura da preduzete mjere budu proporcionalne željenom cilju i da primjena Kodeksa ne vodi nametanju administrativnih i budžetskih tereta izvan razmjera očekivanih koristi. Prema principu konzistentnosti ili dosljednosti Evropska komisija mora

\footnotetext{
10 "Regulation No 31 (EEC), 11 (EAEC), laying down the Staff Regulations of Officials and the Conditions of Employment of Other Servants of the European Economic Community and the European Atomic Energy Community", prečišćena verzija od 1.1.2021. godine, https://eurlex.europa.eu/eli/reg/1962/31(1)/2021-01-01, (18.5.2021). U daljem tekstu koristićemo naziv: Kadrovska pravila.

${ }^{11}$ Odlomak pod naslovom "Područje primjene" u Kodeksu o dobrom ponašanju za osoblje Evropske komisije u odnosima sa javnosti, Poslovnik Komisije, (SL L 308, 8.12.2000), str. 14.

12 "Principles of Good Administration In the Member States of the European Union", The Swedish Agency for Public Management, Stockholm 2005, p. 23.

13 "Handbook on European non-discrimination law", European Union Agency for Fundamental Rights and Council of Europe, Publications Office of the European Union, Luxembourg 2018, p. 23.
} 
biti dosljedna u administrativnom ponašanju i slijediće uobičajenu praksu, a izuzeci od ovog principa moraju biti opravdani i obrazloženi. ${ }^{14}$

\section{4) SMJERNICE ZA DOBRO ADMINISTRATIVNO PONAŠANJE}

U okviru smjernica za dobro administrativno ponašanje od službenika Evropske komisije zahtijeva se objektivnost i nepristrasnost i ažurnost $u$ informisanju o administrativnim procedurama. U okviru zahtjeva za objektivnost i nepristrasnost od službenika se očekuje da uvijek postupa objektivno i nepristrasno $\mathrm{u}$ interesu Zajednice i javnog dobra. ${ }^{15}$ Oni će postupati nezavisno $\mathrm{u}$ okviru politike utvrđene od strane Evropske komisije i u svom ponašanju neće se voditi ličnim ili nacionalnim interesom ili političkim pritiskom. S druge strane, kada su u pitanju zahtjevi stranaka za informacijama koje se tiču administrativnih procedura u Evropskoj komisiji, službenici će pružiti informaciju u rokovima određenim relevantnom procedurom. ${ }^{16}$

\section{5) INFORMACIJE O PRAVIMA ZAINTERESOVANIH STRANA}

U pogledu informacija o pravima zainteresovanih strana službenici Evropske komisije vode računa da saslušaju sve strane sa direktnim interesom, da njihove odluke imaju obrazloženje i da sadrže pouku o pravnom sredstvu.

Saslušanje svih strana sa direktnim interesom podrazumijeva da u situaciji kada komunitarno pravo predviđa da zainteresovane strane trebaju biti saslušane, službenici će im dati priliku da iznesu svoja gledišta. U odlukama koje donosi Evropska komisija trebaju biti jasno iznijeti razlozi na kojima je odluka bazirana i ti razlozi trebaju biti saopšteni licima i strankama kojih se tiču. Opšte pravilo je da treba dati puno obrazloženje. Opšta obaveza svih institucija Evropske unije da daju obrazloženje u svojim aktima je sadržana u članu 296

\footnotetext{
${ }^{14} \mathrm{O}$ spomenutim generalnim principima vidi dio pod naslovom "1. Opšta načela" u Kodeksu o dobrom ponašanju za osoblje Evropske komisije u odnosima sa javnosti, Poslovnik Komisije, (SL L 308, 8.12.2000), str. 14 .

${ }^{15}$ Nepristrasnost službenika podrazumjeva da njihovi stavovi, veze i interesi ne smiju uticati na njihove odluke i da ima pravo da odbije zahtjeve nadređenih kada smatra da nisu u skladu sa propisima. Vidi: Neven Šimac, "Europski upravni prostor i europska načela javne uprave", Zbornik radova Pravnog fakulteta u Splitu, 2012, broj 2, str. 360.

${ }^{16}$ Dio pod naslovom "2. Smjernice za dobro ponašanje” u Kodeksu o dobrom ponašanju za osoblje Evropske komisije u odnosima sa javnosti, Poslovnik Komisije, (SL L 308, 8.12.2000), str. 15.
} 
stav 2 Ugovora o funkcionsanju Evropske unije i članu 41 Povelje o osnovnim pravima Evropske unije. ${ }^{17}$ Međutim, tamo gdje nije moguće detaljno saopštiti razloge odluka, daće se standardano obrazloženje. Standardno obrazloženje treba da uključuje glavne razloge koji opravdavaju donijetu odluku. Međutim, zainteresovanim stranama koje budu to izričito zahtijevale, biće pruženo i detaljno obrazloženje. ${ }^{18}$

Kada komunitarno pravo predviđa u odluci će biti jasno izjavljeno da je moguće uložiti žalbu i biće objašnjeno kako je podnijeti (naziv i adresa odjeljenja, odnosno ime službenika kojem se žalba podnosi i rok za njeno podnošenje). Kada je to potrebno, u odluci treba uputiti na mogućnost pokretanja sudskog postupka ili na mogućnost izjavljivanja žalbe Evropskom ombudsmanu u skladu sa članom $230^{19}$ ili 195 Ugovora o osnivanju Evropske zajednice. ${ }^{20}$

\section{6) POSTUPANJE PO UPITIMA}

Evropska komisija ima obavezu da na upite trećih lica odgovora na odgovarajući način u što kraćem roku. Upiti se odnose na pristup dokumentima, korespondenciju, telefonsku komunikaciju, elektronsku poštu i zahtjeve upućene od medija.

\subsection{ZAHTJEV ZA PRISTUP DOKUMENTIMA I KORESPONDENCIJA}

Kada službenici dobiju zahtjev za pristup određenim dokumentima prvo moraju utvrditi da li je dokument objavljen. Ako je dokument već objavljen, podnosilac zahtjeva se upućuje u Kancelariju za službene publikacije Evropske unije ili u dokumentacione ili informacione centre koji obezbjeđuju slobodan pristup dokumentima, kao što su informacione jedinice, Evropski dokumentacioni centri itd. Mnogi dokumenti su lako dostupni u elektronskoj formi i u takvim slučajevima

\footnotetext{
${ }^{17}$ Ingrid Opdebeek, Stéphanie De Somer, "Duty to Give Reasons in the European Legal Area a Mechanism for Transparent and Accountable Administrative Decision-Making? A Comparison of Belgian, Dutch, French and EU Administrative Law", Public Administration Yearbook 2016 (2), p. 101.

${ }^{18}$ Dio pod naslovom "3. Informacije o pravima zainteresovanih stranaka" u Kodeksu o dobrom ponašanju za osoblje Evropske komisije u odnosima sa javnosti, Poslovnik Komisije, (SL L 308, 8.12.2000), str. 15 .

${ }^{19}$ Prema tablici ekvivalenata radi se o članovima 228 i 263 Ugovora o funkcionisanju Evropske unije.

${ }^{20}$ Dio pod naslovom "3. Informacije o pravima zainteresovanih stranaka" u Kodeksu o dobrom ponašanju za osoblje Evropske komisije u odnosima sa javnosti, Poslovnik Komisije, (SL L $308,8.12 .2000)$, str. 15 .
} 
podnosioca zahtjeva treba uputiti kako traženim dokumentima pristupiti. ${ }^{21}$ Pristupanje dokumentima je obično regulisano posebnim aktima. ${ }^{22}$

Službenici moraju postupiti po zahtjevima jer pravo pristupa dokumentima ima svaki građanin Unije i svaka fizička ili pravna osoba s boravištem ili sjedištem u nekoj državi članici u skladu sa Poveljom o osnovnim pravima Evropske unije i ono ima zadatak da osigura demokratičnost i transparentnost u procesu donošenja odluka. ${ }^{23}$

Po dobijanju upita Evropska komisija daje odgovor na jeziku na kojem je upit upućen, vodeći računa da se radi o jednom od službenih jezika u Evropskoj uniji čime se poštuje ravnopravnost svih službenih jezika. ${ }^{24}$ Odgovor se šalje u roku od 15 radnih dana računajući od datuma prijema upita i u njemu se identifikuje službenik koji je nadležan za davanje odgovora i daje se njegov kontakt. Ako je za odgovor potrebno više od 15 radnih dana, ili je potrebno obaviti prethodne aktivnosti prije slanja odgovora (npr. konsultacije između odjeljenja ili prevođenje), odgovorni službenik će poslati odgovor (holding reply) ${ }^{25}$ u kojem će obavijestiti podnosioca upita da je potrebno određeno vrijeme za izradu i slanje odgovora i ukazati na datum do kojeg se može očekivati dobijanje odgovora, uzimajući u obzir relativnu hitnost i kompleksnost upita. Ako je upit poslan na pogrešnu adresu, upit će službenici proslijediti nadležnima za postupanje i o tome obavjestiti lice koje je poslalo upit. Obavjest sadrži ime i adresu kancelarije službenika kojem je upit proslijeđen. Ova pravila neće se odnositi na korespondenciju koja se može razumno smatrati neprimjerenom. ${ }^{26}$

${ }^{21}$ Kao primjer možemo navesti sljedeću adresu http://eur-lex.europa.eu/en/index.htm адреса Eur-Lex.

${ }^{22}$ Dio pod naslovom "4. Postupanje s upitima" poddio "Zahtjevi za dokumentima" u Kodeksu o dobrom ponašanju za osoblje Evropske komisije u odnosima sa javnosti, Poslovnik Komisije, (SL L 308, 8.12.2000), str. 15.

${ }^{23}$ Margherita Salvadori, "Right of Access to Documents: The Implementation of Article 42 of the Charter of Fundamental Rights Authors", eds. Maria Angela Biasiotti, Sebastiano Faro, From Information to Knowledge, IOS Press, Amsterdam 2011, pp. 39 and 43.

${ }^{24}$ Marijn Chamon, EU Agencies: Legal and Political Limits to the Transformation of the EU Administration, Oxford University Press, New York 2016, p. 173.

${ }^{25}$ U Kodeksu je korišten termin "holding reply" koji se može prevesti kao odgovor kojim se stranka obavještava da će na njen upit biti odgovoreno u određenom roku koji je duži od redovnog roka.

${ }^{26}$ Dio pod naslovom "4. Postupanje s upitima" poddio "Korespondencija” u Kodeksu o dobrom ponašanju za osoblje Evropske komisije u odnosima sa javnosti, Poslovnik Komisije, (SL L 308, 8.12.2000), str. 16. 


\subsection{TELEFONSKA I ELEKTRONSKA KOMUNIKACIJA I ZAHTJEVI OD STRANE MEDIJA}

$\mathrm{Na}$ telefonske pozive službenici odgovaraju odmah ili što je prije moguće. Službenici se moraju identifikovati, što može uključivati i identifikaciju odjeljenja kojem pripadaju, a potrebno je utvrditi i identitet pozivaoca. U odgovoru se mogu dati informacije za koje su službenici direktno odgovorni, u protivnom pozivaoca će uputiti na nadležnog službenika, a po potrebi i na svoje nadređene. Ako je tražena informacija objavljena, pozivalac se upućuje na način na koji može doći do nje. Ako informacija nije objavljena službenik mora utvrditi da li se radi o ličnom ili tajnom podatku ili se radi o informaciji za koju postoji sloboda pristupa. U slučaju ličnih i tajnih podataka potrebno je objasniti pozivaocu da takve podatke nije u mogućnosti otkriti. ${ }^{27}$ Ako se iz konteksta poziva može zaključiti da je bitna pismena potvrda telefonskog upita, službenik može zahtijevati od pozivaoca da mu dostavi takvu potvrdu. ${ }^{28}$

Službenici odgovaraju na elektronsku poštu odmah u skladu sa smjernicama koje se odnose na telefonsku komunikaciju. S obzirom na to da poruke poslane elektronskom poštom po svom sadržaju mogu imati karakteristike upita, službenicima je ostavljena mogućnost da u takvim slučajevima sa takvim porukama postupaju po pravilima koja se odnose na upite..$^{29}$

Kada je zahtjev za informacijama upućen od medija, Informativna služba (The Press and Communication Service) odgovorna je za kontakte sa njima, osim kada se zahtjevi za informacijom odnose na tehnička pitanja koja ulaze u specifične oblasti odgovornosti, kada na njih mogu odgovoriti službenici. ${ }^{30}$

\section{7) ZAŠTITA PODATAKA I ŽALBE}

Zaštita podataka kojima raspolaže Evropska komisija se odnosi na zaštitu ličnih i tajnih podataka. Službenici moraju poštovati pravila o zaštiti privatnosti i ličnih podataka, pravila o poslovnim i službenim tajnama, pravila o tajnosti u

${ }^{27}$ Član 17 Kadrovskih pravila.

${ }^{28}$ Dio pod naslovom "4. Postupanje s upitima" poddio "Telefonsko komuniciranje" u Kodeksu o dobrom ponašanju za osoblje Evropske komisije u odnosima sa javnosti, Poslovnik Komisije, (SL L 308, 8.12.2000), str. 16.

${ }^{29}$ Dio pod naslovom "4. Postupanje s upitima” poddio "Elektronska pošta” u Kodeksu o dobrom ponašanju za osoblje Evropske komisije u odnosima sa javnosti, Poslovnik Komisije, (SL L $308,8.12 .2000)$, str. 16 .

${ }^{30}$ Dio pod naslovom "4. Postupanje s upitima" poddio "Zahtjevi medija" u Kodeksu o dobrom ponašanju za osoblje Evropske komisije u odnosima sa javnosti, Poslovnik Komisije, (SL L 308, 8.12.2000), str. 16. 
krivičnim istragama i povjerljivost pitanja koja ulaze pod nadležnost različitih komiteta i tijela predviđenih u članu 9 i Aneksima II i III Kadrovskih pravila. ${ }^{31}$ Članovi institucija Unije, članovi odbora, funkcioneri i ostali službenici Unije ne smiju, čak ni nakon prestanka njihove dužnosti, otkrivati one podatke koji su obuhvaćeni obavezom čuvanja poslovne tajne, a naročito podatke o preduzećima, njihovim poslovnim odnosima ili troškovima. ${ }^{32}$

Evropska unija se, između ostalog, zasniva i na vrijednosti poštovanja ljudskih prava, tako da ne iznenađuje posvećenost zaštiti podataka jer "zaštita podataka na nivou EU skopčana je sa potrebom zaštite ljudskog prava na privatnost koje je zagarantovano temeljnim pravnim izvorima EU".33 Evropska unija je napravila dodatni iskorak tako što je odredbama koje propisuje zaštitu podataka omogućila i vanteritorijalnu primjenu "čak i u situacijama kada podacima raspolažu entiteti koji inače nisu subjekti EU prava”. ${ }^{34}$

Povrede principa iz Kodeksa za sobom povlače žalbe ${ }^{35}$ koje se mogu uložiti Evropskoj komisiji i Evropskom ombudsmanu. Ako se žalba ulaže Evropskoj komsiji tada se podnosi Generalnom sekretarijatu Evropske komisije. ${ }^{36}$ Generalni direktor

${ }^{31}$ Dio pod naslovom "5. Zaštita ličnih podataka i povjerljivih informacija” u Kodeksu o dobrom ponašanju za osoblje Evropske komisije u odnosima sa javnosti, Poslovnik Komisije, (SL L 308, 8.12.2000), str. 17.

${ }^{32}$ Stephen Weatherill, Cases and Materials on EU Law, Oxford University Press, New York 2014, p. 212.

${ }^{33}$ Mihajlo Vučić, „Granice vanteritorijalnog dejstva Opšte uredbe o zaštiti podataka Evropske unije”, Evropsko zakonodavstvo, 2020, broj 73-74, str. 56.

${ }^{34}$ Ibid.

${ }^{35}$ Ukoliko je stranka pretrpjela štetu zbog nezakonitog ponašanja službenika nekog od organa Evropske unije, postoji mogućnost da se traži naknada štete pred Evropskim sudom pravde. Da bi se naknada štete i dobila potrebno je pored nezakonitog ponašanja institucije dokazati da postoji stvarna šteta i dirktna uzročna veza između ponašanja institucije i nastale štete. T231/97, New Europe Consulting and Michel P. Brown v Commission of European Communities, European Court reports 1999 Page II-02403. Više o postupku vanugovorne odgovornosti može se naći u knjizi: Žan-Klod Zarka, Osnovi institucija Evropske unije, Gualino, Beograd, 2004. godina, str. 83 .

${ }^{36} \mathrm{U}$ obrazcu žalbe potrebno je navesti ime i prezime, adresu, telefon, e-mail adresu i faks žalioca, naziv odjeljenja Evropske Komisije na koji se žali, detaljan opis razloga žalbe uz dokumentaciju koja te razloge potvrđuje ako je to potrebno, odredbu Kodeksa koje je povrijeđena, rezultate koje želimo postići ulaganjem žalbe, izjavu o tome da li je žalilac već kontaktirao odjeljenje na koje se žali u namjeri da dobije naknadu štete i da li je već žalbu uputio Evropskom ombudsmanu. Obrazac se popunjava na stranici Evropske komisije i elektronski podnosi.

https://ec.europa.eu/assets/sg/administrative-conduct/complaints_hr/,(17.5.2021). 
ili rukovodilac uprave odgovara na žalbu pismeno u roku od dva mjeseca. Podnosilac žalbe koji je nezadovoljan odgovorom ima jedan mjesec da podnese zahtjev generalnom sekretaru Evropske komisije da preispita ishod žalbe, koji odgovara na ovaj zahtjev za preispitivanje u roku od mjesec dana. Žalbe mogu biti podnijete Evropskom ombudsmanu u skladu sa Statutom Evropskog ombudsmana. ${ }^{37}$

U ovom slučaju Evropski ombudsman može da postupa po žalbi jer je u njegovoj nadležnosti da prima žalbe od građana Unije ili fizičkih ili pravnih lica s boravištem, odnosno registrovanim sjedištem u državi članici, s tim da žalba ima veze sa nepravilnostima u radu institucija i organa Evropske unije, uz izuzetak Suda Evropske unije u izvršavanju njegovih pravosudnih ovlašćenja. ${ }^{38}$

\section{8) ZAKLJUČAK}

Kodeks dobrog administrativnog ponašanja za službenike Komisije u njihovim odnosima sa javnošću propisuje ponašanje prema strankama i medijima. Radi se o užem regulisanju ponašanja službenika koje se odnosi na odnose sa javnošću. Mišljenje javnosti je bitno za budući razvoj Evropske unije i njenih institucija. Međutim, to nije bio jedini razlog za donošenje Kodeksa. Potreba da se konkretizuje pravo na dobru upravu propisano Poveljom o osnovnim pravima Evropske unije takođe je razlog zbog kojeg se pristupilo izradi Kodeksa. Dosljedno poštovanje pravila Kodeksa ima za rezultat kvalitetniji rad službenika i zadovoljnije stranke, što u krajnjoj liniji treba da ima za rezultat postojanje dobre uprave.

Ponašanje službenika mora biti zakonito, nediskriminatorno, objektivno i nepristrasno. Sve stranke sa direktnim interesom treba saslušati, a odluke koje im se upućuju moraju biti obrazložene i u njima treba navesti pravno sredstvo koje se može koristiti.

Komunikacija sa strankama je podijeljena na pisanu, telefonsku i elektronsku. „Čekajući odogovor" ili "holding reply” je odličan način da se stranka upozna sa razlozima zbog kojih ne može dobiti odgovor u redovnom roku. Mogućnost da se žalba može poslati elektronskim putem je dobar način korištenja modernih tehnologija u radu službenika.

\footnotetext{
${ }^{37}$ Dio pod naslovom “5. Pritužbe” u Kodeksu o dobrom ponašanju za osoblje Evropske komisije u odnosima sa javnosti, Poslovnik Komisije, (SL L 308, 8.12.2000), str. 17.

${ }^{38}$ Nikiforos Diamandouros, "The European Ombudsman and the Application of EU Law by the Member States", Review of European and Administrative Law, Vol. 1, No. 2, 2008, pp. 5-6. Radi se o članu 228 stav 1 Ugovora o funkcionisanju Evropske unije (prečišćena verzija), SL C 202, 7.6.2016, str. 150-151, koji predstavlja bivši član 195 UEZ-a.
} 
U svom radu službenici moraju poštovati pravila o zaštiti ličnih i tajnih podataka. Značaj zaštite ličnih podataka je vezan za poštovanje prava na privatnost, a oba ova prava su zagarantovana Poveljom o osnovnim pravima Evropske unije.

Kodeks kroz svoja pravila nastoji da dobro zaštiti stranke. Ukoliko se obaveze iz Kodeksa ne poštuju, stranka ima pravo da se žali Evropskoj komisiji. Takođe, postoji mogućnost da se stranka obrati Evropskom ombudsmanu. Ukoliko je usljed nezakonitog ponašanja službenika nastala šteta, stranka se može obratiti Evropskom sudu pravde sa zahtjevom za naknadu štete.

\section{9) LITERATURA}

"Principles of Good Administration In the Member States of the European Union", The Swedish Agency for Public Management, Stockholm 2005.

"Handbook on European non-discrimination law", European Union Agency for Fundamental Rights and Council of Europe, Publications Office of the European Union, Luxembourg 2018.

Chamon, Marijn, EU Agencies: Legal and Political Limits to the Transformation of the EU Administration, Oxford University Press, New York 2016.

Diamandouros, Nikiforos, "The European Ombudsman and the Application of EU Law by the Member States", Review of European and Administrative Law, Vol. 1, No. 2, 2008, pp. 5-37.

Koprić, Ivan, Musa, Anamarija, Lalić Novak, Goranka, "Good Administration as a Ticket to the European Administrative Space", Zbornik Pravnog fakulteta Zagreb, 2011, broj 5, pp. 1515-1560.

Lilić, Stevan et al., Upravno pravo, Savremena administracija, Beograd, 1999. godina.

Opdebeek, Ingrid, De Somer, Stéphanie, "Duty to Give Reasons in the European Legal Area a Mechanism for Transparent and Accountable Administrative Decision-Making? A Comparison of Belgian, Dutch, French and EU Administrative Law", Public Administration Yearbook 2016 (2), pp. 97-148.

Salvadori, Margherita, "Right of Access to Documents: The Implementation of Article 42 of the Charter of Fundamental Rights Authors", eds. Maria Angela Biasiotti, Sebastiano Faro, From Information to Knowledge, IOS Press, Amsterdam 2011, pp. 39-53.

Šimac, Neven, "Europski upravni prostor i europska načela javne uprave", Zbornik radova Pravnog fakulteta u Splitu, 2012, broj 2, str. 351-368.

Vala Kristjánsdóttir, Margrét, "Good Administration as a Fundamental Right", Icelandic Review of Politics and Administration, Vol. 9, Issue 1, 2013, pp. 237255. 
Vučić, Mihajlo, "Granice vanteritorijalnog dejstva Opšte uredbe o zaštiti podataka Evropske unije", Evropsko zakonodavstvo, broj 73-74, str. 41-59.

Weatherill, Stephen, Cases and Materials on EU Law, Oxford University Press, New York 2014.

Zarka, Žan-Klod, Osnovi institucija Evropske unije, Gualino, Beograd, 2004. godina.

\section{THE CODE OF GOOD ADMINISTRATIVE BEHAVIOUR FOR STAFF OF THE EUROPEAN COMMISSION IN THEIR RELATIONS WITH THE PUBLIC}

Summary: The work of officials in the institutions of the European Union should be in accordance with its primary and secondary legislation. However, legality in work is only one aspect of officials' behaviour. Other aspects are behaviour towards employees, parties, the media, and the public. In order to cover all components of the conduct of officials, there is the possibility of adopting a Code of Conduct. The aim of this paper is to get acquainted with the Code of Conduct for European Commission officials in their public relations. The paper starts from the hypothesis that the Code is an excellent tool for concretizing the right to good governance and raising the quality of the work of European Commission officials. The results obtained in this paper indicate that the European Commission, through the Code, sought to influence the behaviour of its officials towards parties and the media, ensure data protection, and enable the use of complaints in case of noncompliance with the provisions of the Code.

Keywords: code of conduct for EU officials, European Commission, public relations, good governance. 